\title{
PENGARUH SARI BUAH NANAS (Ananas comosus) DAN LAMA PENYIMPANAN \\ TERHADAP JUMLAH KOLONI BAKTERI DAN KADAR PROTEIN IKAN BANDENG (Chanos chanos) SEBAGAI SUMBER BELAJAR DALAM PERENCANAAN PEMBELAJARAN BIOLOGI MATERI KINGDOM MONERA
}

\author{
Qorry Aulya Rohmana ${ }^{1}$, Poncojari Wahyono ${ }^{1}$, Samsun Hadi ${ }^{1}$ \\ ${ }^{1}$ Pendidikan Biologi FKIP Universtias Muhammadiyah Malang, \\ e-mail: aulyarohmana16@yahoo.com
}

\begin{abstract}
The aims of this research is to know effect of any pineaple extract juice concentration and duration of saving and to determine concentration of the pineaple fruit extract juice and duration of saving which are the most optimal to the sum of bacterial colony and protein degree in bandeng fish. Research type used was True Experiment Design. A scheme used was Complete Random Scheme of factorial pattern. Data was as such the total of bacterial colony and protein contained in bandeng fish. Result of the research shows that concentration of pineaple fruit extract juise and duration of saving effect the bacterial colony total and protein containe in bandeng fish. The total of bacterial colony gets more as the duration of saving gets longer. As for protein contained in the bandeng fish gets lower as the saving duration goes.
\end{abstract}

Key Words : Bandeng Fish, Pineaple, Number of Bacterial colony, Rate of Protein

Ikan bandeng (Chanos chanos Forsk.) adalah jenis ikan air payau yang mempunyai prospek cukup baik untuk dikembangkan karena banyak digemari masyarakat (Purnomowati, 2007). Produksi bandeng secara nasional saat ini menempati urutan ke-enam setelah rumput laut, patin, nila, lele, dan udang. Catatan Kementerian Kelautan Perikanan (KKP) menunjukkan produksi budidaya ikan bandeng meningkat lebih dari $17 \%$ tiap tahunnya. Kasubdit Budidaya Air Payau Laut menyampaikan keterangan, produksi bandeng 2012 tercatat 503.400 ton, dan di 2013 ditarget mencapai 604.000 ton, kemudian diperkirakan pada 2014 akan menembus 700.000 ton (MAI, 2014).

Komoditi perikanan seperti ikan bandeng juga memiliki sifat mudah rusak dan busuk. Ikan bandeng segar memiliki daya simpan hingga 5-8 jam setelah penangkapan. Daya tahan ikan yang sangat singkat ini dipengaruhi juga oleh kadar air pada ikan yang sangat tinggi, yaitu mencapai $80 \%$ berat ikan. Faktor lain yang berperan dalam pembusukan yaitu perubahan yang bersifat enzimatis, mikrobiologis maupun fisis yaitu pada saat pengangkutan dan penyimpanan (Buckle et al, 1987). Salah satu cara untuk menjaga ketahanan dan kualitas pangan adalah dengan cara menambahkan bahan aditif berupa zat antimikroba dalam bentuk pengawetan.

Badan Standardisasi Nasional telah mengeluarkan SNI 7388 tahun 2009 mengenai kualitas mutu pangan berdasarkan cemaran fisik, cemaran kimia dan cemaran mikroba dalam pangan, khusus ikan dan produk perikanan segar termasuk ikan bandeng segar. Penjual ikan banyak yang menggunakan penyimpanan dengan es batu, selain itu masyarakat dirumah juga biasa menyimpan ikan pada suhu kulkas biasa bukan di freezer. Suhu yang biasa digunakan untuk penyimpanan bahan

pangan pada pendinginan adalah $5-10^{\circ} \mathrm{C}$ (Buckle et al, 1987). Pada penyimpanan suhu $15-20^{\circ} \mathrm{C}$ ikan dapat bertahan hingga 2 hari, sedangkan pada suhu $5^{\circ} \mathrm{C}$ tahan selama 5-6 hari tergantung spesies ikan (Mahatmanti et al, 2010). Kecurangan 
paling berbahaya dalam proses pengawetan ikan adalah dengan menambahkan bahan pengawet kimia seperti formalin. Berdasarkan hasil pemantauan dan pengujian yang dilakukan oleh Dinas Peternakan dan Perikanan Enrekang Makassar, di 4 pasar besar yang diambil sampel kebanyakan ikan yang dijual mengandung formalin diantaranya ikan bandeng, lajang, kembung, udang, lajang kering, teri kering, cakalang, serta nila (Fajar, 2013). Oleh karena itu, dibutuhkan alternatif bahan pengawet yang mampu memperpanjang daya simpan ikan bandeng serta tanpa mengubah sifat-sifat pada ikan bandeng. Salah satu yang memiliki potensi untuk pengawetan makanan melalui penghambatan aktivitas mikroba adalah buah nanas.

Nanas (Ananas comosus (L.)

Merr.) banyak mengandung senyawa asam sitrat yang menyebabkan rasa asam pada buah ini, asam sitrat memiliki kemampuan merusak membran bakteri dan memisahkannya dengan sel, sel akan mempertahankan $\mathrm{pH}$ dalam sel yang membutuhkan banyak energi. Nanas juga memiliki kandungan khusus berupa senyawa bromelin yang memiliki fungsi memecah protein membran sel bakteri (Caesarita, 2011). Senyawa fenol memiliki kemampuan mendenaturasi protein sel bakteri (Rakhmanda, 2008). Kandungan asam sitrat, fenol dan senyawa bromelin pada nanas diduga dapat menghambat proses pembusukan ikan oleh mikroorganisme.

Tujuan penelitian ini adalah untuk mengetahui pengaruh sari buah nanas dan lama penyimpanan dan mengetahui konsentrasi sari buah nanas dan lama penyimpanan yang paling optimal terhadap jumlah koloni bakteri dan kadar protein pada ikan bandeng.

\section{METODE PENELITIAN}

Jenis penelitian dalam penelitian ini adalah eksperimen sesungguhnya
(True Experimental Research). Menurut Sugiyono (2010) dikatakan true experimental karena dalam penelitian, peneliti dapat mengontrol semua variabel luar yang mempengaruhi jalannya eksperimen

Desain penelitian yang digunakan pada penelitian ini adalah desain factorial (factorial design) menggunakan dua faktor. Faktor pertama adalah konsentrasi sari buah nanas (Ananas comosus (L.) Merr. ) (A) yang terdiri dari $0 \%, 70 \%$, $80 \%, 90 \%$ dan $100 \%$. Sedangkan faktor kedua adalah lama penyimpanan yang terdiri dari 1, 4 dan 7 hari. Penelitian dilakukan melalui beberapa tahapan yaitu:

1. Mempersiapkan alat dan bahan dan memilih ikan bandeng segar dan utuh dengan berat 100 gr. Kemudian membuat Draw fish ikan bandeng.

2. Merendam Draw fish ikan bandeng dengan sari buah nanas $(70 \%, 80 \%$, $90 \%, 100 \%$ ) selama 45 menit.

3. Menyimpan Draw fish ikan bandeng dalam refrigerator $\left(5^{\circ} \mathrm{C}\right)$ selama 1 hari, 4 hari dan 7 hari.

4. Melakukan pengujian sampel:

a. Uji Total Plate Colony

- Sterilisasi alat dan bahan

- Membuat media agar (Natrium Agar)

- Melakukan pengenceran bertingkat dari sampel yang telah dihaluskan sebanyak 1 gr. Pengenceran dilakukan pada tingkat pengenceran $10^{-3}$ sampai $10^{-5}$.

- Melakukan inokulasi sampel hasil pengenceran pada cawan petri dengan ditambahkan media agar NA dan inkubasi. Media diinkubasikan pada suhu $37 \mathrm{C}$ selama 24 jam.

- Menghitung koloni bakteri dengan menggunakan alat Colony counter. 
b. Uji Kadar Protein (Metode Kjedahl)

- Mempersiapkan alat dan bahan.

- Menghaluskan sampel yang digunakan.

- Menimbang sampel sebanyak 5-10 g.

- Memasukkan sampel kedalam labu kjedahl, lalu menambahkan $2 \mathrm{ml} \mathrm{H}_{2} \mathrm{SO}_{4}$ dan menambahkan 2 gram campuran $\mathrm{Na}_{2} \mathrm{SO}_{4}-\mathrm{HgO}$ (20:1) untuk katalisator.

- Mendidihkan sampai jernih (kurang lebih 4 jam) dan melanjutkan pendidihan 30 menit lagi.

- Setelah dingin, menambahkan $35 \mathrm{ml}$ aquades dan menambahkan $8,5 \mathrm{ml} \mathrm{NaOH}$ $45 \%$ dan melakukan destilasi, destilat ditampung dalam $6,5 \mathrm{ml} \mathrm{H}_{3} \mathrm{BO}_{3} 4 \%$ yang telah diberi tetesan indikator $\mathrm{MM}$ atau MB dan tampung sebanyak $25 \mathrm{ml}$.

- Mentitrasi destilat yang diperoleh dengan $\mathrm{HCl} 0,02 \mathrm{~N}$

Analisis data yang digunakan adalah analisis deskriptif kuantitatif yaitu berupa angka atau data jumlah koloni bakteri (TPC) dan kadar protein. Pengolahan data dilakukan dengan terlebih dahulu menggunakan uji normalitas (Liliefors) dan uji homogenitas (Bartlett), kemudian diteruskan dengan uji Anava 2 Faktor (Two Way Anova) dan uji Beda Nyata Terkecil (BNT).

\section{HASIL}

Berdasarkan penelitian yang telah dilakukan didapatkan hasil jumlah koloni bakteri seperti yang ditunjukkan pada Tabel 1. Rerata hasil berbagai konsentrasi sari nanas dan lama penyimpanan terhadap jumlah koloni bakteri pada ikan bandeng dapat disajikan dalam bentuk diagram seperti pada Gambar 1 .

Tabel 1 dan Gambar 1 menunjukkan bahwa pada tiap-tiap perlakuan konsentrasi sari nanas dan lama penyimpanan didapatkan perbedaan jumlah koloni bakteri. Perlakuan sari nanas dengan konsentrasi 100\% mempunyai rata-rata pertumbuhan jumlah koloni bakteri terendah, dengan jumlah koloni bakteri yang masih dibawah standar SNI $\left(5,0 \quad\right.$ x $\left.10^{5}\right)$ selama penyimpanan hingga 7 hari. Sebaliknya rata-rata jumlah pertumbuhan koloni bakteri tertinggi adalah konsentrasi $0 \%$ dengan perlakuan tanpa pemberian sari nanas sebagai kontrol negatif dengan jumlah koloni bakteri yang sudah melebihi SNI $\left(5,0\right.$ x $\left.10^{5}\right)$ pada penyimpanan 7 hari. Beberapa perlakuan konsentrasi sari nanas, jumlah koloni bakteri berada mendekati diatas nilai SNI setelah perlakuan 7 hari.

Berdasarkan penelitian yang telah dilakukan didapatkan hasil kadar protein serti pada Tabel 2. Rerata hasil berbagai konsentrasi sari nanas dan lama penyimpanan terhadap kadar protein pada ikan bandeng dapat disajikan dalam bentuk diagram seperti pada Gambar 2 .

Berdasarkan Tabel 2 dan Gambar 2 menunjukkan bahwa pada tiap-tiap perlakuan konsentrasi sari nanas dan lama penyimpanan didapatkan perbedaan rerata kadar protein pada ikan bandeng. Perlakuan sari nanas dengan konsentrasi $100 \%$ mempunyai rata-rata jumlah kadar protein paling tinggi pada penyimpanan hingga 7 hari. Sebaliknya rata-rata jumlah kadar protein paling rendah adalah konsentrasi $0 \%$ dengan perlakuan tanpa pemberian sari nanas sebagai kontrol negatif dengan penurunan kadar protein yang relatif tinggi hingga penyimpanan 7 hari. Perlakuan konsentrasi sari nanas juga menunjukkan penurunan kadar protein namun kadar protein masih lebih tinggi dibandingkan perlakuan kontrol. 
Setelah data yang diperoleh berdistribusi normal dan homogen, maka dapat dilanjutkan dengan uji anava dua faktor taraf signifikansi 0,05 dan hasilnya dapat dilihat pada Tabel 3. Berdasarkan hasil uji anava dua faktor seperti tercantum pada Tabel 3 diketahui bahwa nilai $F_{\text {hitung }} \mathrm{A} \times \mathrm{B}(3.213)>\mathrm{F}_{\text {tabel }} \mathrm{A} \times \mathrm{B}$ (2.266) berarti ada pengaruh berbagai konsentrasi sari nanas (Ananas comosus (L.) Merr.) dan lama penyimpanan terhadap pertumbuhan jumlah koloni bakteri pada ikan bandeng. Ada pengaruh sari buah nanas dan lama penyimpanan terhadap jumlah koloni bakteri ikan bandeng pada taraf $5 \%$ dan $1 \%(* *)$.

Berdasarkan Tabel 4 dapat dilihat adanya nilai antara selisih kelompok kontrol dan kelompok perlakuan penyimpanan hari pertama kurang dari nilai BNT 5\%, artinya antara kedua kelompok ini tidak memiliki perbedaan nyata. Jika dilihat dari data diatas pengujian selanjutnya yaitu kelompok kontrol dan kelompok perlakuan hari ke-7 menunjukkan angka lebih dari nilai BNT $5 \%$ yang artinya antara kedua kelompok ini berbeda nyata. Semakin besar nilai dari selisih kelompok pasangan semakin tinggi pula perbedaan antara kelompok tersebut.

Setelah data yang diperoleh berdistribusi normal dan homogen, maka dapat dilanjutkan dengan uji anava dua faktor taraf signifikansi 0,05 dan hasilnya dapat dilihat pada Tabel 5. Berdasarkan hasil uji anava dua faktor taraf 5\% seperti tercantum pada Tabel 5 diketahui bahwa nilai $F_{\text {hitung }} \mathrm{A} \times \mathrm{B}(2.532)>\mathrm{F}_{\text {tabel }} \mathrm{A} \times \mathrm{B}$ (2.266) berarti ada pengaruh berbagai konsentrasi sari nanas (Ananas comosus (L.) Merr.) dan lama penyimpanan terhadap kadar protein pada ikan bandeng.

Selanjutnya berdasarkan Tabel 6 dapat dilihat adanya Nilai antara selisih kelompok perlakuan (konsentrasi 100\% lama penyimpanan hingga 7 hari) dan kelompok kontrol (lama penyimpanan hingga 7 hari) dengan nilai BNT 5\% menunjukkan $0,812 \quad(1,06-0,248)$, artinya antara kedua kelompok ini memiliki perbedaan yang nyata. Jika dilihat dari data diatas kesemua kelompok berbeda nyata. Semakin rendah nilai dari selisih kelompok pasangan semakin rendah pula perbedaan antara kelompok tersebut.

\section{PEMBAHASAN}

Berdasarkan hasil penelitian tentang pengaruh sari buah nanas (Ananas comosus (L.) Merr.) dan lama penyimpanan terhadap jumlah koloni bakteri pada ikan bandeng menggunakan uji anava dua faktor dari perlakuan berbagai konsentrasi sari buah nanas dan berbagai lama penyimpanan 1, 4 hingga 7 hari menunjukkan bahwa ada pengaruh pemberian sari buah nanas dan lama penyimpanan terhadap jumlah koloni bakteri pada ikan bandeng.

Hasil penelitian menunjukkan bahwa semakin tinggi konsentrasi sari buah nanas yang digunakan maka semakin sedikit jumlah koloni bakteri. Hal ini dikarenakan semakin tinggi konsentrasi sari nanas (Ananas comosus (L.) Merr.), maka pertumbuhan bakteri akan semakin dihambat pertumbuhannya sehingga terjadi perbedaan hasil jumlah koloni bakteri pada ikan bandeng. Hal tersebut sejalan dengan pernyataan Pelczar dan Chan (1988) bahwa konsentrasi bahan antimikroba, dengan semakin tinggi konsentrasi bahan antimikroba maka semakin tinggi daya penghambatan terhadap aktivitas mikroba.

Selain itu lama penyimpanan yang berbeda juga sangat mempengaruhi jumlah koloni bakteri pada ikan bandeng. Semakin lama penyimpanan ikan, bakteri yang masih ada pada ikan bandeng masih mampu beraktivitas meskipun diperlambat dan diminimalisir dengan adanya pemberian sari buah nanas 
sehingga jumlah koloni bakterinya juga semakin tinggi.

Pemberian berbagai konsentrasi dalam menghambat pertumbuhan bakteri seiring dengan lama penyimpanan. Jumlah koloni yang terendah terdapat pada lama penyimpanan terendah, sedangkan semakin lama penyimpanan yang digunakan semakin banyak jumlah koloni bakteri yang dihasilkan (Tilawah, 2012).

Menurut Eshamah et al (2013) komponen antimikroba pada buah nanas adalah senyawa bromelin. Mekanisme kerja antimikroba bromelin adalah dengan mengubah atau merusak struktur dinding luar bakteri yang mengandung protein. Bromelin akan memecah dan mendenaturasi protein penyusun dinding sel bakteri, akibatnya dinding sel bakteri akan melemah dan menyebabkan sel mengalami kebocoran atau pecah.

Kandungan asam sitrat pada buah nanas sekitar $87 \%$ dari total asam yang terkandung didalamnya (Whiting, 1970). Asam sitrat merupakan golongan asam organik yang memiliki $\mathrm{pH}$ asam, $\mathrm{pH}$ asam pada nanas sekitar 3,71 (Anonimous, 2009). Pada dasarnya $\mathrm{pH}$ netral bakteri adalah 5-8 untuk perkembangbiakan dan melakukan aktivitasnya.

Menurut Skrivanova et al (2006), asam organik mampu menembus membran lipid dari sel bakteri dan memisahkannya dengan sel. Karena bakteri mempertahankan $\mathrm{pH}$ netral dalam sitoplasma selnya, maka dilakukan pengangkutan proton yang berlebih. Pengangkutan ini membutuhkan banyak ATP selular dari dalam sel bakteri, lama kelamaan sel tidak mampu memproduksi energi kembali dan akhirnya sel mengalami kehabisan energi untuk mempertahankan hidupnya.

Fungsi antimikroba lain juga disebabkan karena adanya senyawa fenol (quercetin, flavone-3-ol, dan flavon) (Mhatre et al, 2009). Senyawa ini merupakan senyawa turunan flavonoid. Mekanisme kerjanya dengan cara mendenaturasi protein sel bakteri dan merusak membran sel tanpa dapat diperbaiki lagi (Nuria dkk, 2009). Selain itu juga menyebabkan penyusun utama membran sel yaitu ion $\mathrm{Ca} 2+$ (kalsium) kehilangan kemampuannya untuk menganggkut bahan-bahan terlarut ke dalam sitoplasma atau organel-organel sel, tanpa kehadiran ion ini membran sel akan bocor. Dimana bahan-bahan yang sudah diangkut ke dalam sitoplasma atau organela akan merembes keluar. Fungsi kalsium pada membran ini adalah berperan mengikat bagian hidrofilik satu sama lain dengan gugusan dari molekul protein pada permukaan membran (Lay, 1992).

Penelitian ini selain menggunakan penambahan senyawa antibakteri buah nanas tetapi juga dilakukan penyimpanan ikan bandeng pada suhu $\quad 5^{\circ} \mathrm{C}$, hal ini bertujuan untuk menghambat aktivitas mikroba dan reaksi -reaksi kimiawi yang dapat menurunkan mutu ikan bandeng Suhu penyimpanan bahan pangan biasanya pada $5-10^{\circ} \mathrm{C}$, karena hampir semua bakteri patogen hanya mampu memperbanyak diri dengan laju lambat pada suhu dibawah $10^{\circ} \mathrm{C}$ (Gaman dan Sherrington, 1992 dalam Kencana, 2009). Namun pada suhu tersebut masih ada beberapa golongan mikroba yang mampu melakukan pertumbuhan dan beraktivitas seperti golongan bakteri psikrofil yang optimum pada suhu 5-15C (Fardiaz, 1992 dalam Waluyo ， 2004). Sehingga walaupun disimpan pada suhu dingin $5{ }^{\circ} \mathrm{C}$, semakin lama penyimpanan jumlah koloni bakteri juga akan semakin meningkat, dengan penambahan sari buah nanas dan seiring lama penyimpanan pada suhu $5{ }^{\circ} \mathrm{C}$, aktivitas bakteri dapat dihambat atau dihentikan.

Konsentrasi sari buah nanas yang berbeda menunjukkan perbedaan angka jumlah koloni bakteri, semakin tinggi konsentrasi sari buah nanas semakin 
rendah pula jumlah koloni bakteri pada ikan bandeng. Pemberian sari buah nanas dan dengan lama penyimpanan tertentu mampu mempengaruhi kadar protein pada ikan bandeng. Pengaruh antar perlakuan berbeda nyata pada masingmasing perlakuan.

Interaksi keduanya memberikan pengaruh yang nyata terhadap jumlah koloni bakteri pada ikan bandeng. Semakin tinggi konsentrasi sari buah nanas yang diberikan pada ikan bandeng akan menurunkan jumlah koloni bakteri yang ada, meskipun lama penyimpanan juga menaikkan jumlah koloni bakteri yang ada. Namun dengan konsentrasi tinggi sari jumlah koloni bakteri pada lama penyimpanan hingga 7 hari masih berada dibawah standar SNI $\left(5,0 \times 10^{5}\right)$. Sehingga ikan bandeng masih aman dikonsumsi hingga pada lama penyimpanan 7 hari. Perlakuan yang menunjukkan jumlah koloni bakteri berada diatas $\operatorname{SNI}\left(5,0 \times 10^{5}\right)$ sebaiknya tidak untuk dikonsumsi karena tercemar dengan jumlah bakteri yang melebihi ambang batas.

Hasil penelitian pengaruh sari buah nanas dan lama penyimpanan terhadap kadar protein menunjukkan bahwa semakin tinggi konsentrasi sari buah nanas yang digunakan penurunan kadar protein yang terjadi tidak sesignifikan penurunan kadar protein pada perlakuan konsentrasi $0 \%$ (kontrol).

Hal ini disebabkan karena pada konsentrasi tinggi sari buah nanas masih ada beberapa bakteri yang mampu bertahan hidup, namun jumlah bakteri yang mampu bertahan hidup ini tidak sebanyak pada ikan bandeng dengan pemberian sari nanas konsentrasi rendah, sedangkan pada konsentrasi rendah sari buah nanas memungkinkan lebih banyak mikroorganisme yang menyebabkan kerusakan protein ikan bandeng. Seiring dengan lamanya waktu penyimpanan, mikroorganisme akan semakin banyak. Adanya aktivitas mikroorganisme tersebut memicu terjadinya reaksi enzimatik yang dapat merubah struktur penyusun ikan karena mikroorganisme mengkonsumsi asam amino sehingga menyebabkan pengurangan sejumlah gugus $\mathrm{N}$ dari asam amino penyusun (Ikayanti, 2007).

Penggunaan sari buah nanas sebagai anti mikrobial alami yang ditambahkan pada ikan untuk memperpanjang daya simpannya dalam penelitian ini dapat dijadikan sebagai materi pengembangan untuk melakukan percobaan yang terkait dengan materi Eubacteria pada kompetensi inti 4 dan kompetensi dasar 4.6.

\section{Kompetensi Inti:}

4. Mengolah, menalar, dan menyaji dalam ranah konkret dan ranah abstrak terkait dengan pengembangan dari yang dipelajarinya di sekolah secara mandiri, dan mampu menggunakan metoda sesuai kaidah keilmuan

\section{Kompetensi Dasar :}

4.6 Melakukan percobaan pengamatan koloni bakteri pada medium buatan di berbagai lokasi dan menghubungkannya dengan penanggulangannya menggunakan desinfektan, sabun, antis, karbol dan lain-lain serta melaporkannya dalam bentuk laporan.

Perencanaan pembelajaran biologi
pada materi Archaebateria dan
Eubactaeria, ciri, karakter, dan
peranannya akan dikaitkan dengan
kegiatan percobaan menggunakan hasil
penilitian yang telah dilakukan,
perencanaan pembelajaran ini selanjutnya
akan dilengkapi dengan modul
pengayaan.

\section{KESIMPULAN DAN SARAN}

\section{Kesimpulan}

Ada pengaruh konsentrasi sari buah nanas (Ananas comosus (L.) Merr.) dan lama penyimpanan terhadap jumlah koloni bakteri dan kadar protein pada 
ikan bandeng (Chanos chanos Forsk.), pada konsentrasi sari buah nanas $80 \%$ dan lama penyimpanan 7 hari yang berpengaruh paling optimal terhadap jumlah koloni bakteri yang masih dibawah standar SNI, dan pada konsentrasi $100 \%$ dengan lama penyimpanan 1 hari yang berpengaruh optimal pada kadar protein ikan bandeng. Penerapan hasil penelitian ini dijadikan sebagai sumber belajar berupa modul dalam perencanaan pembelajaran biologi materi Kindom Monera.

\section{Saran}

Berdasarkan hasil penelitian ini disarankan beberapa hal berikut. Pertama, pengawetan dengan menggunakan bahan alami pada ikan bandeng yang disarankan untuk produsen dan masyarakat konsumen ikan bandeng yaitu menggunakan sari buah nanas (Ananas comosus (L) Merr.) $80 \%$ dengan lama penyimpanan 7 hari pada suhu $5^{\circ} \mathrm{C}$. Kedua, penyimpanan ikan bandeng dengan menggunakan sari buah nanas (Ananas comosus (L) Merr) konsentrasi $100 \%$ agar penyimpanan yang dilakukan bisa lebih dari 7 hari. Selain itu, perlu dilakukan penelitian serupa, dengan melakukan uji organoleptik sehingga dapat diketahui pengaruh pemberian sari buah nanas terhadap daya terima masyarakat pada mutu fisik dan rasa ikan bandeng tersebut.

\section{DAFTAR PUSTAKA}

Anonimous, 2009. Pineapple. (Online). (http://www.

hoomebrewtalk.com./. Diakses 02 Agustus 2014).

AOAC, 2005. Oficial Method of Asociation of Oficial Analytical Chemist. 12th Editon. Published by Asociation of Oficial Analytical Chemist. Benjamin Franklin Station. Washington.

Badan Standardisasi Nasional. 2009. Batas Maksimum Cemaran
Mikroba dalam Pangan. SNI 7388:2009. ICS 67.220.2009.

Bansode, D.S and Chavan M.D. 2013. Evaluation of Antimicrobial Activity and Phytochemical Analysis of Papaya and Pineapple Fruit Juices Against Selected Enteric Pathogens. International Journal of Pharma and Bio Sciences ISSN 0975-6299. Pharm Bio Sci 2013 Apr; 4(2): (B) 1176 $-1184$

Buckle, K. A., Edward, R. A., Fleet, H. G., Wootton, M. 1987. Ilmu Pangan. Jakarta: Universitas Indonesia Press.

Caesarita, D.P. 2011. Pengaruh Ekstrak Buah Nanas (ananas comosus) $100 \%$ terhadap Bakteri Staphylococcus aureus dari Pioderma. Tugas Artikel Ilmiah. Semarang: UNDIP.

Chavan, M. 2013. Antimicrobial activity of fruit juices against multidrug resistant shigella species. Journal of Pharmaceutical and Cosmetic Sciences Vol. 1(2) Pp. 33-35, 26 June, 2013

Eshamah, H., Han, I., Naas, H., Rieck.J, Dawson, P. 2013. Bactericidal Effects of Natural Tenderizing Enzymes on Escherichia Coli and Listeria monocytogenes. Journal of Food Research; Vol. 2, No. 1; 2013

Fajar. 2013. Waspada, Kebanyakan Ikan Kandung Formalin. (Online). (http://www.fajar.co.id/metromak assar/ Diakses 26 Juni 2014).

Fardiaz, D. 1992. Teknik Analisa SIfat

Kimia dan Fungsional Komponen Pangan. Bogor: ITP.

Fardiaz, S. 1993. Mikrobiologi Pangan I. Jakarta : Gramedia Pustaka Utama

Fardiaz, S. 1994. Pengendalian Keamanan dan Penerapan HACCP Dalam Perusahaan Jasa Boga. Buletin Teknologi dan 
Industri Pangan, No.5 Vol.3, Hal 71-77.

Gaman, P.M. dan Sherrington, K.B. 1992. ILMU PANGAN: Pengantar Ilmu Pangan Nutrisi dan Mikrobiologi, Edisi Kedua. Yogyakarta: UGM Press.

Hadiwiyoto, Suwedo. 1993. Teknologi Pengolahan Hasil Perikanan Jilid 1. Yogjakarta: Liberty.

Ikayanti, Yuli. 2007. Pengaruh Suhu dan Lama Penyimpanan terhadap Jumlah Koloni Bakteri dan Kandungan Protein pada Sosis Ikan Lele Dumbo (Clarias Gariepinus). Skripsi. Malang: Universitas Islam Negeri Malang

Kepala Pusat Penyuluhan Kelautan dan Perikanan. 2011. Materi Penyuluhan Pengolahan ikan bandeng. Modul. Jakarta. 1-2 hal.

Lay, B. W. 1994. Analisis Mikroba di Laboraturium. Edisi 1. Jakarta: P.T Raja Grafindo Persada

Lay, B \& Sugyo, H. 1992. Mikrobiologi. Jakarta: Rajawali Press

MAI (Masyarakat Akuakultur Indonesia). 2014. Bandeng: Indonesia Masih Jawara. $\quad$ (Online). (http://www.aquaculture-mai.org/. Diakses 26 Juni 2014).

Mahatmanti, W.F, Warlan Sugiyo, Wisnu Sunarto. 2010. Sintesis Kitosan dan Pemanfaatan sebagai Anti Mikrobia Ikan Segar. Jurnal Sains dan Teknologi ISSN.0213-1366. Vol.8 no. 2 .

Mhatre, M., Tilak-Jain, J., De, S., \& Devasagayam, T.P.A. 2009. Evaluation of the antioxidant activity of non-transformed and transformed pineapple: A comparative study. Food and Chemical Toxicology, 47, 26962702.

Nuria, Maulita Cut dkk. 2009. Uji aktivitas antibakteri ekstrak etanol daun jarak pagar (Jatropha curcas L.) terhadap bakteri
Staphylococcus aureus ATCC 25923, Escherichia coli ATCC 25922, Dan Salmonella typhi ATCC 1408. MediaAgro VOL 5. NO 2, 2009: HAL 26-37

Pelczar, M.J. dan Chan, E.C.S. 1988. Dasar-dasar Mikrobiologi 1. Jakarta: UI Press.

Purnomowati, I., Hidayati, D., dan Saparinto, C. 2007. Ragam Olahan Bandeng. Yogyakarta: Kanisius.

Rakhmanda, A.P. 200 8. Perbandingan Efek Antibakteri Jus Nanas (Ananas comosus L.merr) pada Berbagai Konsentrasi terhadap Streptococcus mutans. Tugas Artikel Ilmiah. Semarang: Universitas Diponegoro.

Skrivanova, E. et al. 2006. Susceptibility of Escherichia coli, Salmonella $s p$. and Clostridium perfringens to organic acids and monolaurin. Journal of Veterinarni Medicina, 51, 2006 (3): 81-88

Sugiono. 2010. Metode Penelitian Pendidikan. Bandung: Alfabeta.

Tilawah, Anis W. 2012. Efektivitas berbagai konsentrasi sari buah belimbing wuluh (Averrhoa bilimbi Linn) dan lama penyimpanan terhadap jumlah koloni bakteri dan kadar histamin fillet ikan tuna (Thunnus sp). Skripsi. Malang: Skripsi Universitas Muhammadiyah Malang

Waluyo, Lud. 2004. Mikrobiologi Umum. Malang: UMM Press

Waluyo, Lud. 2010. Teknik dan Metode Dasar dalam Mikrobiologi. Malang: UMM Press

Whiting, G. C. 1970. Constituents of Fruits : Sugars. Di dalam : A. C. Hulme ed.

The Biochemistry of Fruits and Their Products. Vol. 1. Academic Press. London 
Tabel 2. Hasil pengamatan jumlah koloni bakteri pada ikan bandeng

\begin{tabular}{|c|c|c|c|c|c|}
\hline \multirow[t]{3}{*}{ Perlakuan } & \multicolumn{5}{|c|}{ Jumlah Koloni Bakteri (CFU per ml) } \\
\hline & \multicolumn{3}{|c|}{ Ulangan } & \multirow[t]{2}{*}{ Total } & \multirow[t]{2}{*}{ Rata } \\
\hline & I & II & III & & \\
\hline A1B1 & $6,0 \times 10^{4}$ & $1,5 \times 10^{5}$ & $8,7 \times 10^{4}$ & $2,9 \times 10^{5}$ & $9,8 \times 10^{4}$ \\
\hline A1B2 & $2,8 \times 10^{5}$ & $2,4 \times 10^{5}$ & $3,4 \times 10^{5}$ & $8,6 \times 10^{5}$ & $2,9 \times 10^{5}$ \\
\hline A1B3 & $1,2 \times 10^{6}$ & $1,8 \times 10^{6}$ & $1,1 \times 10^{6}$ & $4,2 \times 10^{6}$ & $1,4 \times 10^{6}$ \\
\hline $\mathrm{A} 2 \mathrm{~B} 1$ & $1,5 \times 10^{5}$ & $8,6 \times 10^{4}$ & $3,3 \times 10^{4}$ & $2,7 \times 10^{5}$ & $8,9 \times 10^{4}$ \\
\hline $\mathrm{A} 2 \mathrm{~B} 2$ & $1,2 \times 10^{5}$ & $7,9 \times 10^{4}$ & $1,9 \times 10^{5}$ & $3,8 \times 10^{5}$ & $1,3 \times 10^{5}$ \\
\hline A2B3 & $1,1 \times 10^{6}$ & $4,7 \times 10^{5}$ & $3,0 \times 10^{4}$ & $1,6 \times 10^{5}$ & $5,3 \times 10^{5}$ \\
\hline A3B1 & $5,6 \times 10^{4}$ & $1,2 \times 10^{5}$ & $8,1 \times 10^{4}$ & $2,6 \times 10^{5}$ & $8,6 \times 10^{4}$ \\
\hline A3B2 & $3,2 \times 10^{4}$ & $7,1 \times 10^{4}$ & $2,1 \times 10^{5}$ & $3,1 \times 10^{5}$ & $1,0 \times 10^{5}$ \\
\hline A3B3 & $7,2 \times 10^{5}$ & $4,6 \times 10^{5}$ & $4,0 \times 10^{4}$ & $1,2 \times 10^{6}$ & $4,1 \times 10^{5}$ \\
\hline A4B1 & $6,4 \times 10^{4}$ & $1,0 \times 10^{5}$ & $7,3 \times 10^{4}$ & $2,4 \times 10^{5}$ & $8,0 \times 10^{4}$ \\
\hline A4B2 & $9,6 \times 10^{4}$ & $1,3 \times 10^{5}$ & $4,5 \times 10^{4}$ & $2,7 \times 10^{5}$ & $9,1 \times 10^{4}$ \\
\hline A4B3 & $3,1 \times 10^{4}$ & $4,9 \times 10^{5}$ & $4,9 \times 10^{5}$ & $1,0 \times 10^{6}$ & $3,4 \times 10^{5}$ \\
\hline A5B1 & $6,0 \times 10^{4}$ & $6,5 \times 10^{4}$ & $8,8 \times 10^{4}$ & $2,1 \times 10^{5}$ & $7,1 \times 10^{4}$ \\
\hline A5B2 & $2,0 \times 10^{5}$ & $3,1 \times 10^{4}$ & $3,1 \times 10^{4}$ & $2,6 \times 10^{5}$ & $8,7 \times 10^{4}$ \\
\hline A5B3 & $6,6 \times 10^{4}$ & $1,8 \times 10^{5}$ & $7,1 \times 10^{5}$ & $9,5 \times 10^{5}$ & $3,2 \times 10^{5}$ \\
\hline \multicolumn{4}{|c|}{ Jumlah } & $1,2 \times 10^{7}$ & $4,1 \times 10^{6}$ \\
\hline
\end{tabular}

Jumlah Koloni Bakteri

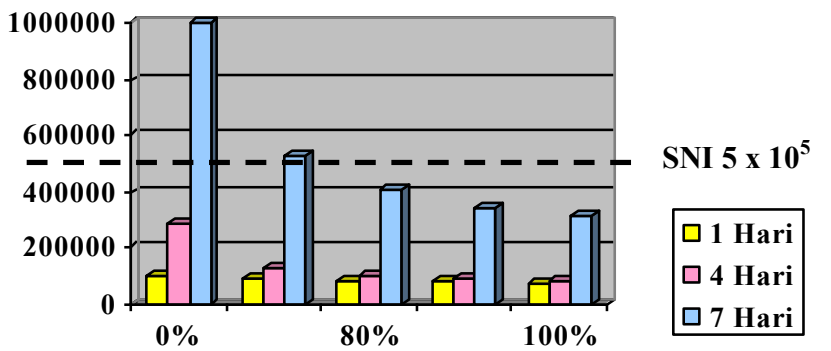

(Kontrol) Konsentrasi Sari Nanas Lama Penyimpanan

Gambar 1. Diagram batang rerata jumlah koloni bakteri pada ikan bandeng

Tabel 2. Hasil pengamatan kadar protein ikan bandeng

\begin{tabular}{|c|c|c|c|c|c|}
\hline \multirow[t]{3}{*}{ Perlakuan } & \multicolumn{5}{|c|}{ Kadar Protein (gram) } \\
\hline & \multicolumn{3}{|c|}{ Ulangan } & \multirow[t]{2}{*}{ Total } & \multirow[t]{2}{*}{ Rata } \\
\hline & $\mathbf{I}$ & II & III & & \\
\hline A1B1 & 19.44 & 19.26 & 19.09 & 57.78 & 19.26 \\
\hline A1B2 & 18.21 & 18.03 & 18.25 & 54.50 & 18.16 \\
\hline A1B3 & 17.69 & 17.33 & 17.51 & 52.53 & 17.51 \\
\hline $\mathrm{A} 2 \mathrm{~B} 1$ & 19.61 & 19.61 & 19.79 & 59.01 & 19.67 \\
\hline A2B2 & 18.39 & 18.21 & 18.39 & 54.98 & 18.33 \\
\hline A2B3 & 17.86 & 18.03 & 17.86 & 53.76 & 17.92 \\
\hline A3B1 & 19.96 & 19.79 & 19.96 & 59.71 & 19.90 \\
\hline A3B2 & 18.56 & 18.56 & 18.46 & 55.58 & 18.53 \\
\hline A3B3 & 18.21 & 18.03 & 18.21 & 54.46 & 18.15 \\
\hline A4B1 & 20.14 & 20.31 & 20.14 & 60.58 & 20.19 \\
\hline A4B2 & 18.74 & 18.56 & 18.60 & 55.90 & 18.63 \\
\hline A4B3 & 18.39 & 18.56 & 18.39 & 55.33 & 18.44 \\
\hline A5B1 & 20.49 & 20.49 & 20.31 & 61.28 & 20.43 \\
\hline A5B2 & 19.09 & 18.91 & 19.00 & 57.00 & 18.99 \\
\hline \multirow[t]{2}{*}{ A5B3 } & 18.74 & 18.67 & 18.74 & 56.14 & 18.71 \\
\hline & Jumlal & & & 848.53 & 282.84 \\
\hline
\end{tabular}


Kadar Protein(gram)

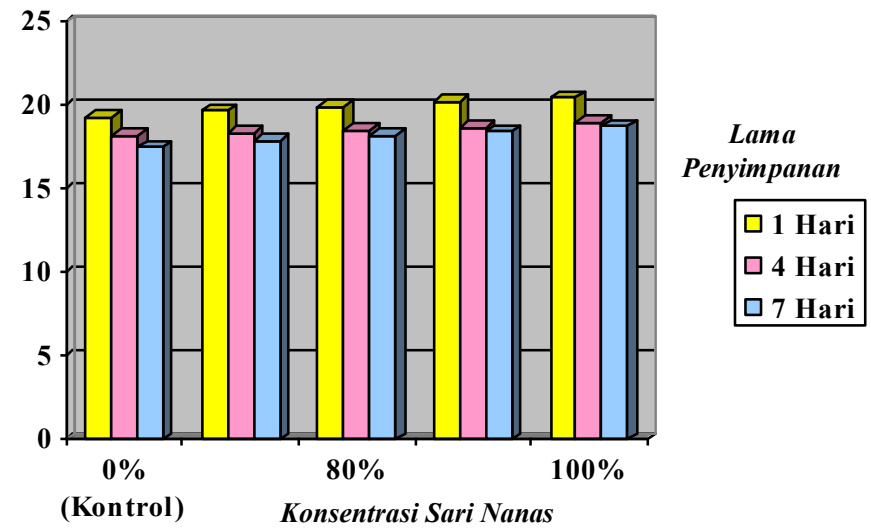

Gambar 2. Diagram batang rerata kadar protein pada ikan bandeng

Tabel 3. Hasil ringkasan uji analisis varian dua faktor konsentrasi sari nanas dan lama penyimpanan terhadap jumlah koloni bakteri pada ikan bandeng

\begin{tabular}{llllllll}
\hline SK & DB & JK & KT & F.Hit & Notasi & $\begin{array}{l}\text { F.Tab } \\
\mathbf{5 \%}\end{array}$ & $\begin{array}{l}\text { F.Tab } \\
\mathbf{1 \%}\end{array}$ \\
\hline Perlakuan & 14 & $4.8938 \mathrm{E}+12$ & $3.5 \mathrm{E}+11$ & 6.6798 & $* *$ & 2.03 & 2.741 \\
\hline P.A1 & 4 & $1.1812 \mathrm{E}+12$ & $2.95 \mathrm{E}+11$ & 5.6429 & $* *$ & 2.68 & 4.017 \\
\hline P.B2 & 2 & $2.3674 \mathrm{E}+12$ & $1.18 \mathrm{E}+12$ & 22.619 & $* *$ & 3.31 & 5.390 \\
\hline P.A1.B2 & 8 & $1.3452 \mathrm{E}+12$ & $1.68 \mathrm{E}+11$ & 3.2133 & $* *$ & 2.26 & 3.173 \\
\hline Galat & 30 & $1.5699 \mathrm{E}+12$ & $5.23 \mathrm{E}+10$ & & & & \\
\hline Total & 44 & $6.4637 \mathrm{E}+12$ & & & & & \\
\hline
\end{tabular}

Keterangan pengambilan keputusan :

- $\quad \mathrm{F}_{\text {hitung }} \mathrm{A} \times \mathrm{B}>\mathrm{F}_{\text {tabel }} \mathrm{A} \times \mathrm{B}=$ Ho ditolak/Hi diterima (Ada pengaruh)

- $\quad \mathrm{F}_{\text {hitung }} \mathrm{A} \times \mathrm{B}<\mathrm{F}_{\text {tabel }} \mathrm{A} \times \mathrm{B}=$ Ho diterima (Tidak ada pengaruh)

- $\quad$ Notasi : *berbeda nyata, ns : tidak berbeda

Tabel 4. Hasil Ringkasan Uji BNT 5\% konsentrasi sari nanas dan lama penyimpanan terhadap jumlah koloni bakteri ikan bandeng (Pengujian terencana)

\begin{tabular}{|c|c|c|c|c|}
\hline No & Kelompok Pasangan & $\begin{array}{l}\text { Selisih } \\
\text { Pasangan }\end{array}$ & $\begin{array}{l}\text { Nilai } \quad \text { BNT } \\
\mathbf{5 \%}\end{array}$ & Kesimpulan \\
\hline 1 & A1B1: (A2B1,A3B1,A4B1, A5B1) & 16917 & 301527 & Tidak berbeda nyata \\
\hline 2 & A1B2: (A2B2,A3B2,A4B2, A5B2) & 184133,3 & 301527 & Tidak berbeda nyata \\
\hline 3 & A1B3: (A2B3,A3B3,A4B3, A5B3) & 991885,5 & 301527 & Berbeda nyata \\
\hline
\end{tabular}

Keterangan pengambilan keputusan: ui - ui' $>$ BNT0.05 $\Rightarrow$ Berbeda nyata

Tabel 5. Hasil ringkasan uji analisis varian dua faktor konsentrasi sari nanas dan lama penyimpanan terhadap kadar protein pada ikan bandeng

\begin{tabular}{cccccccc}
\hline SK & DB & JK & KT & F.Hit & Notasi & $\begin{array}{c}\text { F.Tabel } \\
5 \%\end{array}$ & $\begin{array}{c}\text { F.Tabel } \\
1 \%\end{array}$ \\
\hline Prlkuan & 14 & 31.4974 & 2.24981 & 190.4 & $* *$ & 2.037 & 2.741 \\
\hline P.A1 & 4 & 6.05277 & 1.51319 & 128.06 & $* *$ & 2.689 & 4.017 \\
\hline P.B2 & 2 & 25.2053 & 12.6026 & 1066.5 & $* *$ & 3.315 & 5.390 \\
\hline P.A1.B2 & 8 & 0.23935 & 0.02992 & 2.532 & $*$ & 2.266 & 3.172 \\
\hline Galat & 30 & 0.35449 & 0.01181 & & & & \\
\hline Total & 44 & 31.8519 & & & & & \\
\hline
\end{tabular}


Keterangan pengambilan keputusan :

- $\quad \mathrm{F}_{\text {hitung }} \mathrm{A} \times \mathrm{B}>\mathrm{F}_{\text {tabel }} \mathrm{A} \times \mathrm{B}=$ Ho ditolak/Hi diterima (Ada pengaruh)

- $\quad \mathrm{F}_{\text {hitung }} \mathrm{A} \times \mathrm{B}<\mathrm{F}_{\text {tabel }} \mathrm{A} \times \mathrm{B}=$ Ho diterima (Tidak ada pengaruh)

- Notasi: *berbeda nyata, ns : tidak berbeda

Tabel 7. Hasil Ringkasan Uji BNT 5\% konsentrasi sari nanas dan lama penyimpanan terhadap kadar protein ikan bandeng (Pengujian terencana)

\begin{tabular}{ccccc}
\hline No & Kelompok Pasangan & Selisih Pasangan & Nilai BNT 5\% & Kesimpulan \\
\hline 1 & $\begin{array}{c}\text { (A5B1,A5B2,A5B3): } \\
\text { (A1B1,A1B2,A1B3) }\end{array}$ & 1,06 & 0,248 & Berbeda nyata \\
\hline 2 & $\begin{array}{c}\text { (A4B1,A4B2,A4B3): } \\
\text { (A1B1,A1B2,A1B3) }\end{array}$ & 0,78 & 0,248 & Berbeda nyata \\
\hline 3 & $\begin{array}{l}\text { (A3B1,A3B2,A3B3): } \\
\text { (A1B1,A1B2,A1B3) }\end{array}$ & 0,55 & 0,248 & Berbeda nyata \\
\hline 4 & $\begin{array}{c}\text { (A2B1,A2B2,A2B3): } \\
\text { (A1B1,A1B2,A1B3) }\end{array}$ & 0,328 & 0,248 & Berbeda nyata \\
\hline
\end{tabular}

Keterangan pengambilan keputusan: ui - ui' > BNT0.05 => Berbeda nyata 